\title{
FORMS AT THE BASE OF TILL STRATA AS INDICATORS OF ICE MOVEMENT
}

\author{
By J. EhLers \\ (Geologisches Landesamt Hamburg, Oberstrasse 88, D-200o Hamburg I3, Germany) \\ and H.-J. Stephan \\ (Geologisches Landesamt Schleswig-Holstein, Mercatorstrasse 7, D-230o Kiel 21, Germany)
}

\begin{abstract}
The direction of inland ice movement can, in some case;, be reconstructed by a study of the forms at the base of till strata. These forms are "ribs", which are formed either as slickensides or as a type of negative "flute"; "edges" and "wedges", which are caused by shearing movements at the base of the ice; or "undulations", probably created by restricting movements at the base of the ice. These forms appear to be elongated in the direction of ice movement. As these features can easily be measured, they can be used to check, supplement, or replace the results of till-fabric measurements.
\end{abstract}

RÉsumé. Formes à la base des. dépôts morainiques comme indicateurs des mouvements de la glace. La direction des mouvements de la glace continentale peut, dans cértains cas, être reconstituće par une étude des formes à la base des dépôts morainiques. Ces formes sont des "nervures", qui sont formées soit comme des reliefs latéraux proprement dits, soit comme une sorte de "flute" en négatif; des "arêtes" ou des "coins" qui sont produits par des mouvements de cisaillement à la base de la glace ou des "ondulations" créées probablement par des - mouvements d'ampleur restreinte à la base de la glace. Ces formes apparaissent comme allongées dans la direction du mouvement de la glace. Comme ces caractéristiques peuvent être facilement mesurées, on peut les utiliser pour contrôler, suppléer ou accroitre les résultats des mesures sur la texture de la moraine.

Zusammenfassung. Formen am Gründe von Moränenbänken als Indikatoren der Eisbewegung. In einigen Fällen lässt sich die bewegungsrichtung des Inlandeises durch Formen an der Unterseite von Moränenbänken rekonstruieren. Es handelt sich hierbei um Rippen, die entweder als Harnische oder eine Art negativer "flutes" gebildet werden, um Kanten und Keile, die durch Scherbewegungen an der Basis des Eises entstehen, oder um Wellen, die vermutlich durch einengende Bewegungen in der Eis erzeugt werden. All diese Formen weisen nach bisherigen Beobachtungen eine Längserstreckung in der Richtung der Eisbewegung auf. Da diese Bewegungsmarken leicht eingemessen werden können, bietet sich die Möglichkeit, die Ergebnisse von Geschiebe-Einregelungsmessungen zu überprüfen, zu ergänzen oder auch zu ersetzen.

\section{INTRODUCTION}

To reconstruct the direction of glacier flow is a frequent aim of glacial geological investigations. The simplest and best way is to measure striations on the surface of bedrock. But only in very few cases is it possible to find striations in areas with glacial deposits. Examples have been published by Seifert (1952) and Stephan (I97I) from east Holstein, where striations on drift boulders at the base of a till stratum reflect the direction of glacier flow. Over the past few years, however, we have repeatedly found lineations at the contact between till strata and the underlying sediments which allow us to reconstruct the direction of ice movement. The localities studied are shown in Figure $\mathrm{I}$.

\section{OBSERVEd PHENOMENA \\ "Ribs"}

In several cases "ribs" were found at the base of till strata protruding into the underlying sediment. In all the cases studied the strike of the crest is parallel or nearly parallel to the direction of ice movement reconstructed by other methods. They generally vary between several centimetres and o. I $\mathrm{m}$ in width and the same is true of their height. In some places larger examples are found. Sometimes, however, very small, often short "ribs" no more than a few millimetres in width are found. 


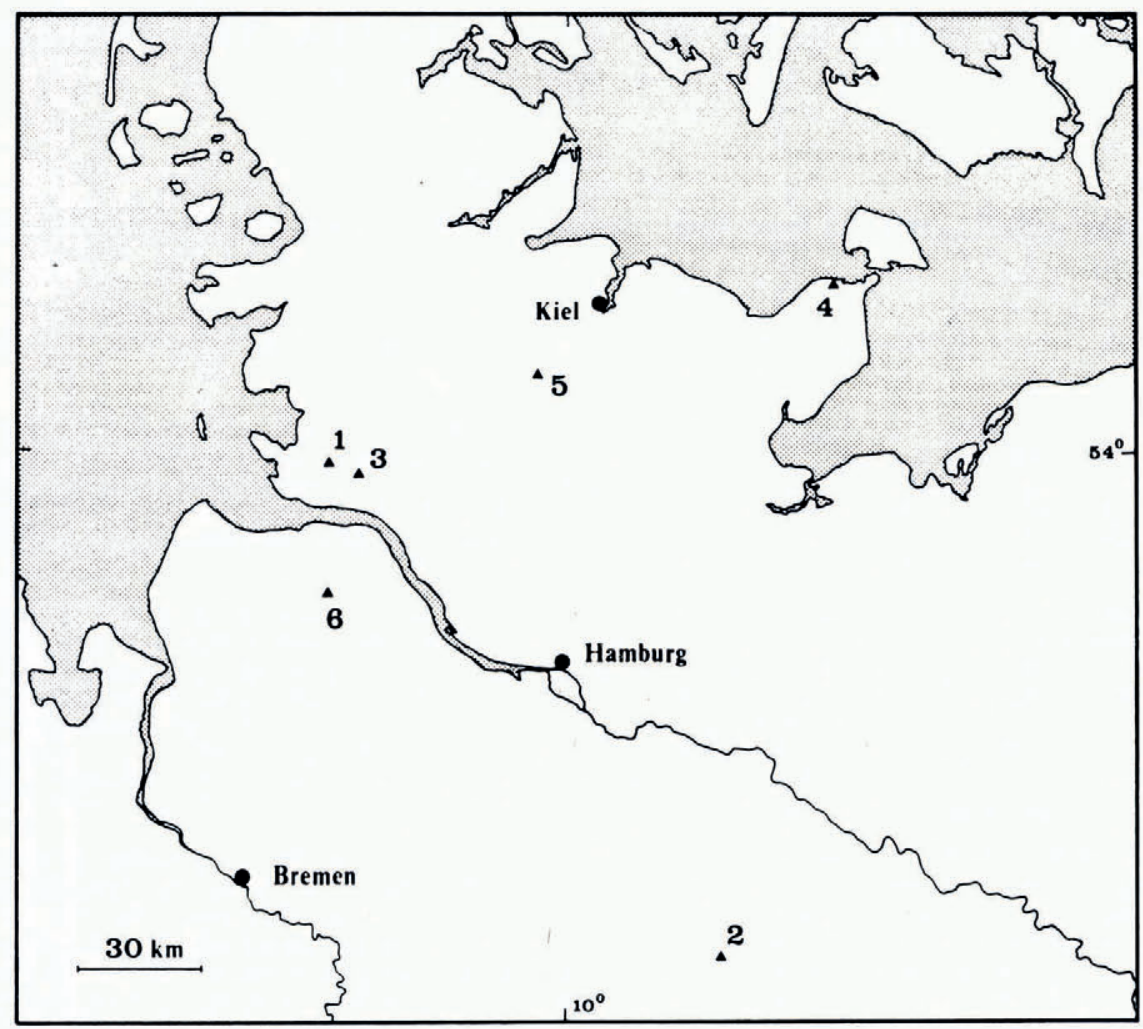

Fig. I. Map of north Germany showing the localities which were studied: 1. St. Michaelisdonn; 2. Elbe-Seiten canal; 3. Burg in Dithmarschen; 4. Heiligenhafen; 5. Borgdorf; 6. Chalk quarry, Hemmoor.

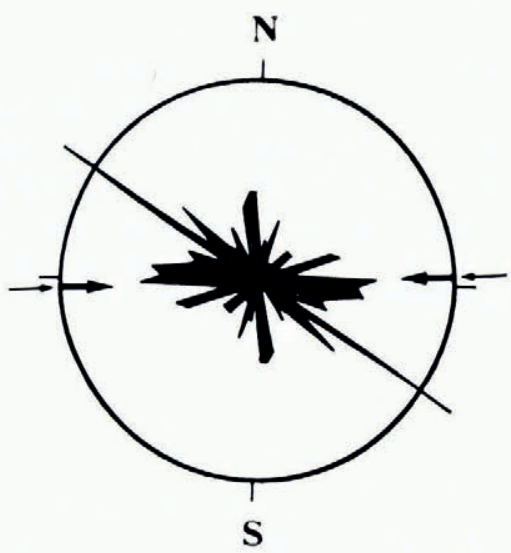

Fig. 2. Till-fabric measurements at St. Michaelisdonn; till of the Main Drenthe Advance. 93 measurements of long axes; the circle indicates $10 \%$. Heavy arrow in the circle: direction of striae on stones conlained in the till. Light arrow: direction of "ribs" on the underside of the till. 
I. One of the first places to be examined was St. Michaelisdonn in Schleswig-Holstein. Several years ago a gravelly sand up to $8 \mathrm{~m}$ thick was quarried there. Underlying this was a till up to $1.8 \mathrm{~m}$ thick, which was grey, comparatively rich in stones and gravels, and only partly weathered. According to G. Schlüter's* study of indicator boulders (personal communication), it is a till of the Drenthe stage (Saalian). The measurements of till fabric by G. Seifert* gave pronounced maxima around $090^{\circ}$ and $125^{\circ}$ (see Fig. 2). Striae on the till stones had an average strike of $087^{\circ}$. An almost identical strike was found on "ribs" on the lower surface of the till stratum (personal communication from H. Ross*).

2. The construction of the Elbe-Seiten canal from the Elbe up to the Mittelland canal gave us the unique opportunity of studying an almost continuous profile through Lower Saxony's Pleistocene deposits.

At kilometre 6o.6 of the canal (north of Esterholz and south of Uelzen) the following profile was exposed:

(a) Greyish brown, sandy basal till up to $8 \mathrm{~m}$ thick. Till-fabric measurement gave a preferred orientation of $025^{\circ}$ (see Fig. 3). This direction is typical for the Main Drenthe basal till of the first Saalian ice advance in this area.

(b) Fine sand about $4 \mathrm{~m}$ thick. This has humus layers containing re-worked lignite and occasionally amber. This humus material is probably re-worked Tertiary sediments. The sands are slightly glacially deformed.

(c) Blackish grey basal till. Till-fabric measurement gave a preferred orientation of $35^{\circ}$. This till is considered by us to be of Elsterian age.

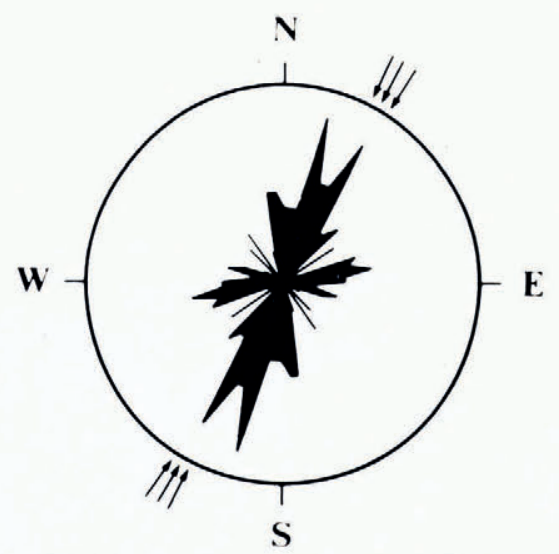

Fig. 3. Till-fabric measurements at the Elbe-Seiten canal south of Uelzen; till of the Main Drenthe Advance. I3o measurements of long axes; the circle indicates $10 \%$. Arrows: direction of "ribs" on the underside of the till.

The lower surface of the Drenthe basal till was not planar but showed clear undulations. When the underlying fine sand was scraped away, elongated "ribs" were exposed-all orientated at about $030^{\circ}$, and thus roughly parallel with the direction of the ice movement inferred from the till-fabric measurements. Large fragments of till which had fallen from the exposure wall and which lay upside down (Figs 4 and 5) showed that the underside of the till had a corrugated form with some of the ribs no wider than a few millimetres.

\footnotetext{
* Geologisches Landseamt Schleswig-Holstein.
} 

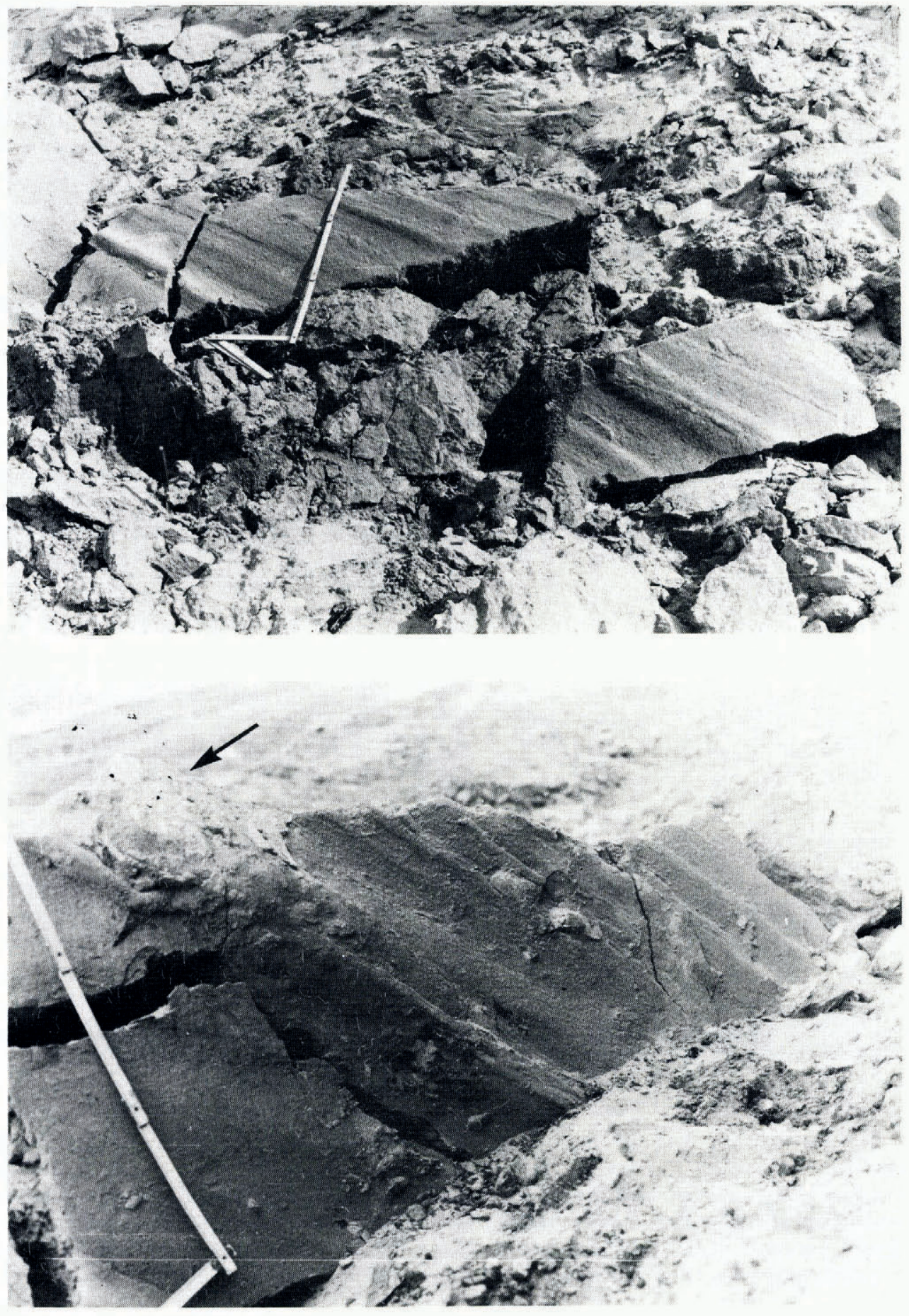

Figs 4 and 5. Construction site of the Elbe-Seiten canal south of Velzen. Corrugated frattern at the underside of the Main Drenthe till; one "rib" ending at a stone (Fig. .5, see arrow). (Photographs by. J. Ehlers, 1975.) 
3. At a site south of Burg in Dithmarschen the following succession was observed:

(a) Gravelly sand-3.5-4.2 m.

(b) Reddish brown till of Drenthe age-0.6-1.o m; containing isolated streaks of sand and sandy layers. Its base is very gravelly.

(c) Medium sand $-4 \mathrm{~m}$.

(d) Gravel-2.5 m exposed.

At the base of the till there were several small undulations. When the underlying sand was dug away, these undulations were found to be "ribs" with an average strike of $085^{\circ}$ (see Figs 6-8). Till-fabric measurements in the till stratum at two different places, $40 \mathrm{~m}$ apart from each other, showed maxima of $075^{\circ}$ and $070^{\circ}$ (Fig. 9). In the latter case, the fabric is relatively weak and it is considered that the "ribs" gave the better indication of the direction of movement.
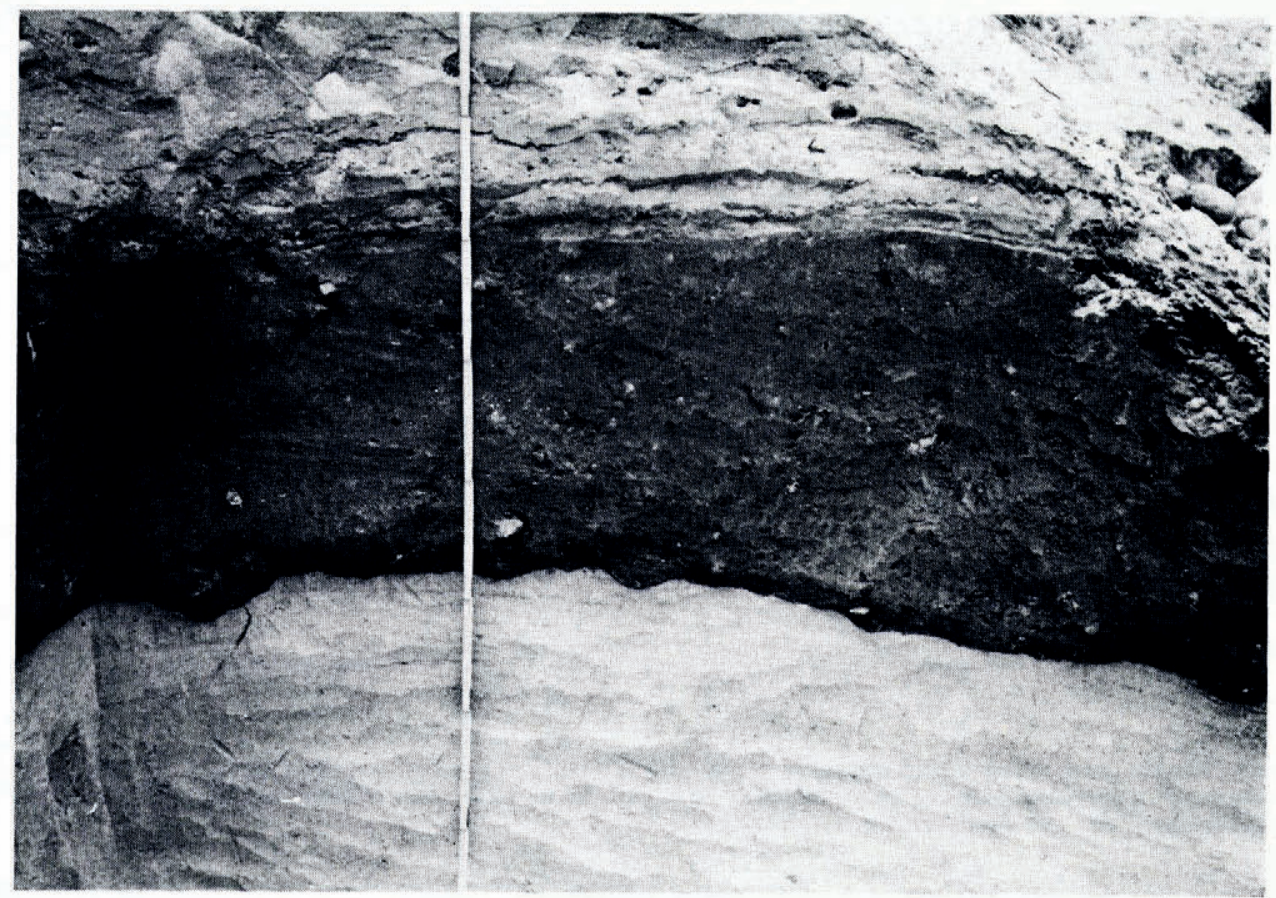

Fig. 6. Burg/Dithmarschen, south of Paradiestal. Main Drenthe till, o.6 $m$ thick, overlain and underlain by melt-water sands. At the base of the till bank are vertically cut "ribs". Facing west. (Photograph by H.-7. Stephan, 1977.)

How did such "ribs" form? In a few cases the distal ends of these "ribs" could be found. A stone was always situated there in the underside of the till. From this we can infer that the "ribs" may have been formed by a furrowing of the underlying sediment caused by till stones (cf. Figs 5 and 7, arrows) which were carried along on the underside of the ice as "basal debris". In the lee of these stones, basal till material was pressed into the furrows in a process probably not unlike that of the formation of flutes described by Boulton (1976) and Morris and Morland ( 1976 ). The difference is in the fact that in the formation of flutes the ice itself is furrowed; in the present cases it is the land surface. The till "ribs" are the moulds of furrows and grooves in the underlying sediment, the moulds of glacial striations. 


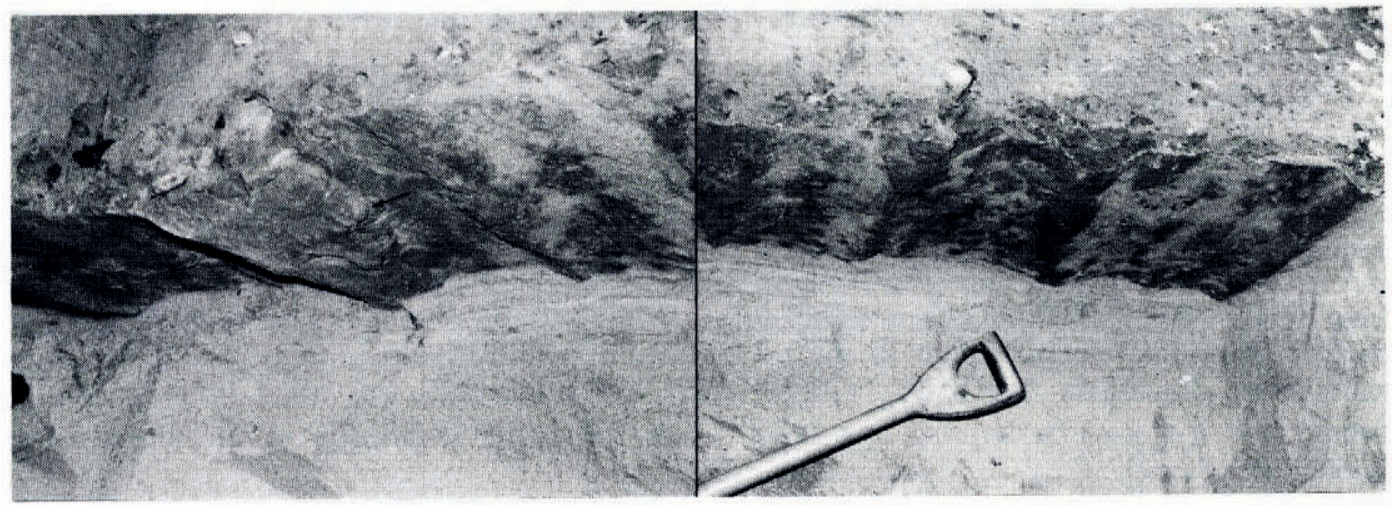

Figs 7 and 8. Burg/Dithmarschen, south of Paradiestal. In the upper part of the photographs is the Main Drenthe till with "ribs" at its base; the underlving sand is dug awav.

Fig. 7. Left-hand part of Figure 6 ; the arrow indicates the location of a till stone.

Fig. 8. Central part of Figure 6.

Taken with flashlight. (Photographs by H.-J. Stephan, 1977.)
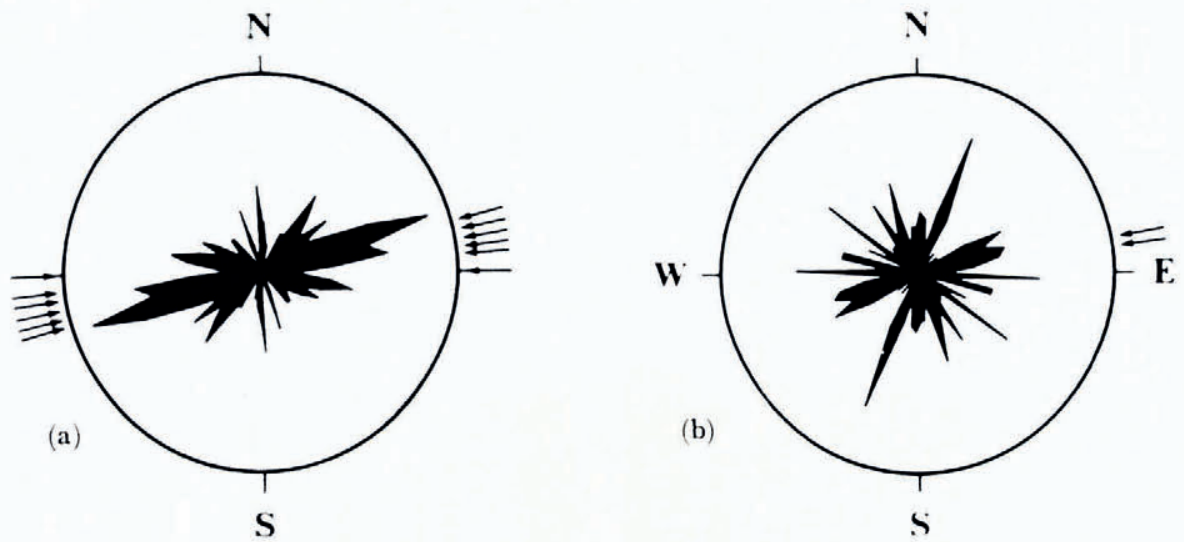

Fig. 9. Till-fabric measurements at Burg/Dithmarschen: till of the Main Drenthe Advance. (a) $13^{8}$ measurements of long axes. (b) 142 measurements of long axes about $40 \mathrm{~m}$ east of $(a)$. The circle indicates $10^{\circ}{ }_{0}$ in both cases. Arrows: direction of "ribs" on the underside of the till.

\section{"Slickensides"}

Near Heiligenhafen in east Holstein, an extensive complex of folds formed by glacial deformation is exposed in a cliff on the Baltic coast. In the eastern section, extremely chalky, sandy light grey till occurs. This till is the bottommost stratum and appears in anticlinal fold cores. It contains isolated silty and gravelly sand strata (extremely sandy morainic material). On top of this lowest till is a grey till which is full of fissures. The two tills are discordantly overlain by a till $0.5^{-1.5} \mathrm{~m}$ in thickness which is believed to represent the late Weichselian "Fehmarn Advance" (see Stephan, 1971). According to the till-fabric measurement in the till of the "Fehmarn Advance" and to the numerous striations on boulders below its base, the ice advanced at that time in an east-west direction.

On the eastern flank of the easternmost exposed anticlinal fold some striated stones were found on an upthrow plane. The striations had an average strike of $090^{\circ}$. After a flood, a thrust plane rising to the west was exposed, and above this was a stratum of sandy till resting 
on chalky till. The upper surface of the lower chalky till was ribbed in a corrugated fashion (Fig. 10). Most of the "ribs" and furrows were about $5 \mathrm{~cm}$ wide and their strike was approximately east to west $(082)$. There is no doubt that they were moulded on the interface between the two tills during the movement of the east-west ice advance.

Although the forms exposed at the Heiligenhafen cliff are somewhat similar to those described before, they were formed in a different way. At Heiligenhafen, two till strata moved one over the other. leading to the formation of a slickenside.

\section{"Edges"}

Sudden changes in the inclination of the lower surface of the till frequently occur along well-defined lines striking parallel to the direction of ice movement. The term "edges" is suggested for the small interfaces thus formed. Good examples of this are illustrated in Olszewski (1974, p. I Io and I 13; "pressing contacts").

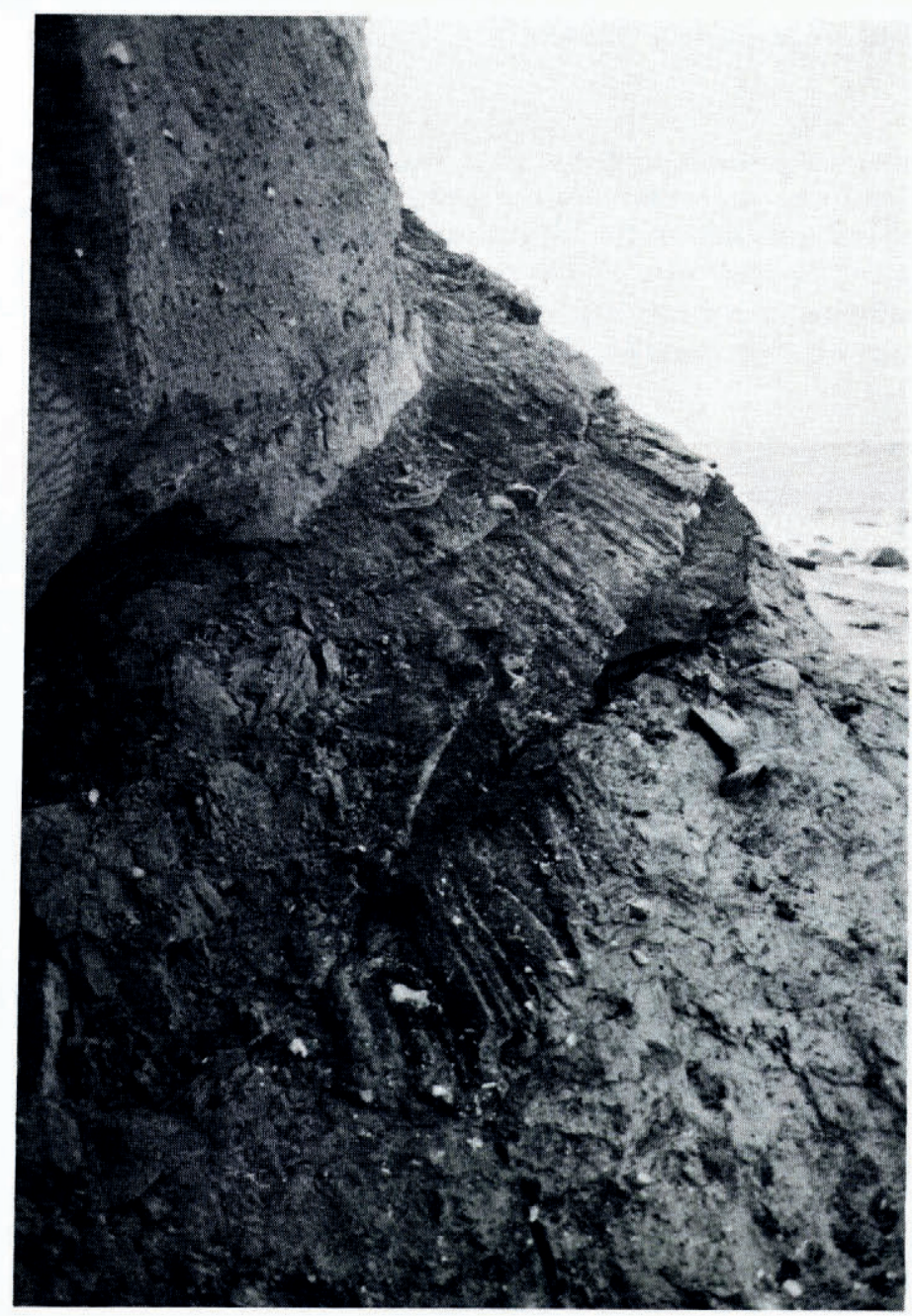

Fïg. 1o. Heiligenhafen cliff. Slickensides. (Photograph by H.-7. Stephan, 1978.) 
A basal till at Lake Borgdorf, south-west of Kiel, is a further example. Lake Borgdorf is situated in the marginal area of the Weichselian glaciation. A lobe of the Weichselian inland ice went over that area in a south-south-westerly direction, corresponding to the elongation of Lake Borgdorf. The measurements of the "edges" on the lower surface of the till exposed there show a similar direction (average strike of $019^{\circ}$; cf. Fig. I I).

E

W

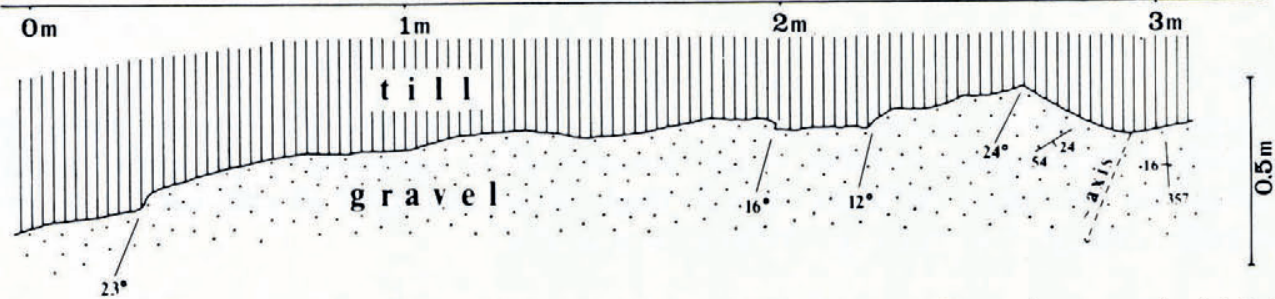

Fig. II. Borgdorf, south-west of Kiel. Sketch of the interface between a till bank and underlying melt-water sands with "edges" (slightly simplified). On the right is an "undulation".

"Wedges"

Sometimes there are small wedge-shaped masses of till which are found at the lower surface of a till stratum, projecting into the underlying sediment, mainly in zones where the inclination of the lower surface of the till stratum changes, or at the flanks of larger "undulations" (see below). "Wedges" are to be seen at the lower surface of the till stratum in Figure 12 (exposure of Hemmoor) to the extreme left and also right of the centre. The term "wedge" for such forms has already been used by Olszewski (1974, p. I I I).

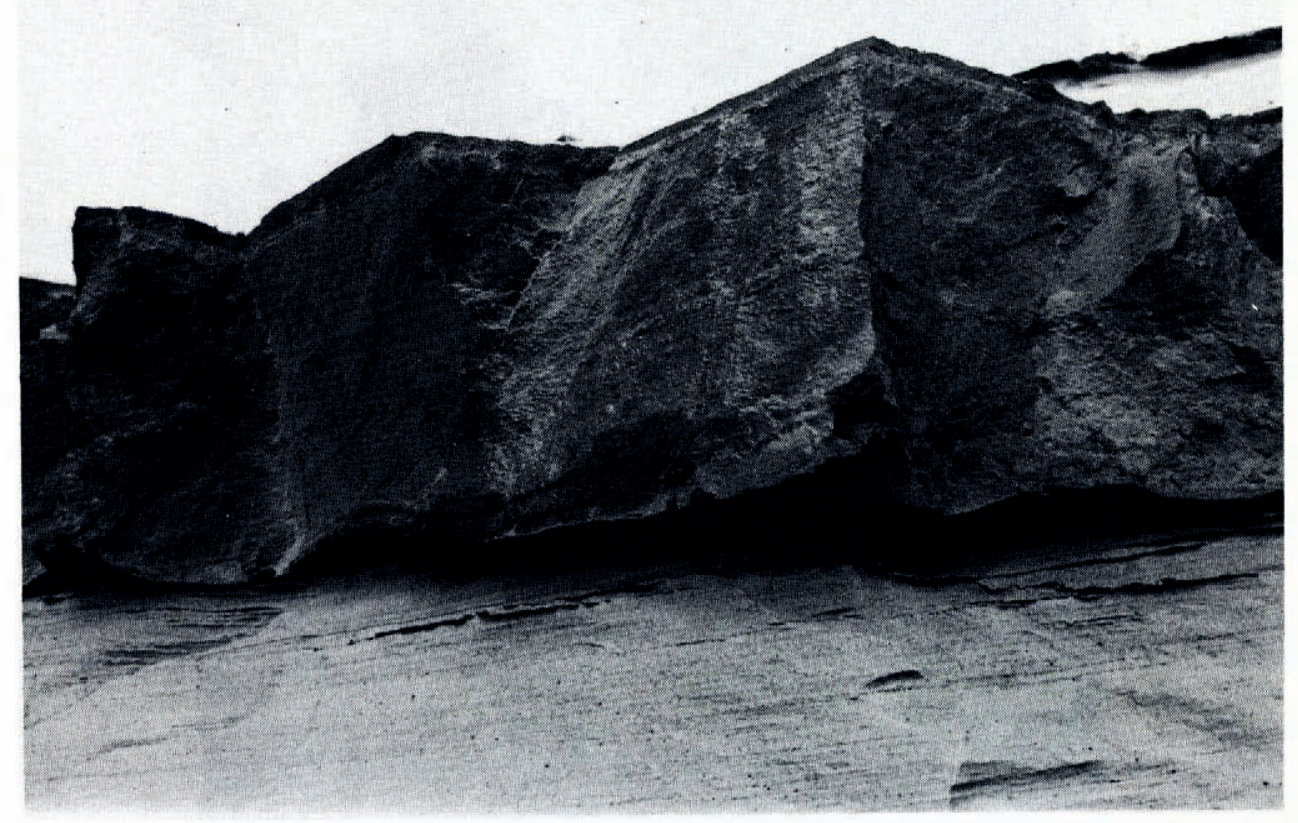

Fig. 12. Chalk quarry at Hemmoor. At the base of the Main Drenthe till "undulations" are to be seen. Facing east. (Photograph by 7 . Ehlers, 1977.) 
As a rule, "edges" and "wedges" strike parallel to the direction of the local ice movement. Both features were probably formed at the base of the ice. The authors believe that "wedges" are formed by restricting shearing movements, directed approximately perpendicular to the direction of ice flow. If no further movement takes place in the basal zone of the ice after the formation of "edges" and "wedges", they are preserved as very distinct forms. In other cases they are more or less worn and rounded (cf. Fig. II). Therefore, it is not always easy to tell the difference between these forms and the "ribs" described above.

\section{"Undulations"}

Broad slight "undulations" of the lower surface of a till stratum are very common. Occasionally, undulations with a shorter wavelength are found forming distinct synclines and anticlines. The crests are usually anything from one to several metres apart. Sometimes only single synclines occur, protruding into the underlying sediment. The term "undulation" is suggested for all these features. They are rarely symmetrical. In places they have an elliptical or lancet-like form. A divergent strike can thus be measured on both sides of an "undulation" (cf. Fig. I I, right-hand side).

The examples found in the field support the theory that the axes of these "undulations" lie parallel to the flow direction of the ice. Their strike is easily measured if "edges" or "wedges" occur on their flanks (cf. Fig. 12) and this is quite often the case. Figure I 2 shows undulations of this type in the chalk quarry at Hemmoor. Below the clayey Niendorf till of the mid-Saalian glaciation, there are several metres of sands and a sandy basal till of the Main Drenthe Advance up to I m thick. The gravel accumulation on the surface of this till suggests that it was partly re-worked. In certain places, the till is completely eroded and only the stones are left. The Drenthe till is only partly weathered. Underlying it were found undisturbed decalcified melt-water sands.

Till-fabric measurements in the Main Drenthe till by F. Grube (Geologisches Landesamt Hamburg) and H.-C. Höfle (Niedersächsisches Landesamt für Bodenforschung) showed a maximum of $060^{\circ}$ (personal communication). Earlier measurements by Ehlers (1975) in another part of the same quarry gave a preferred orientation of $015^{\circ}$ and $025^{\circ}$.

On the underside of the basal till of the Main Drenthe Advance were groove-like "undulations" about $5 \mathrm{~cm}$ in width which had been eroded out by the wind (Fig. I I) and which lay between broader synclinal "undulations". All forms showed a strike of between $060^{\circ}$ and $065^{\circ}$.
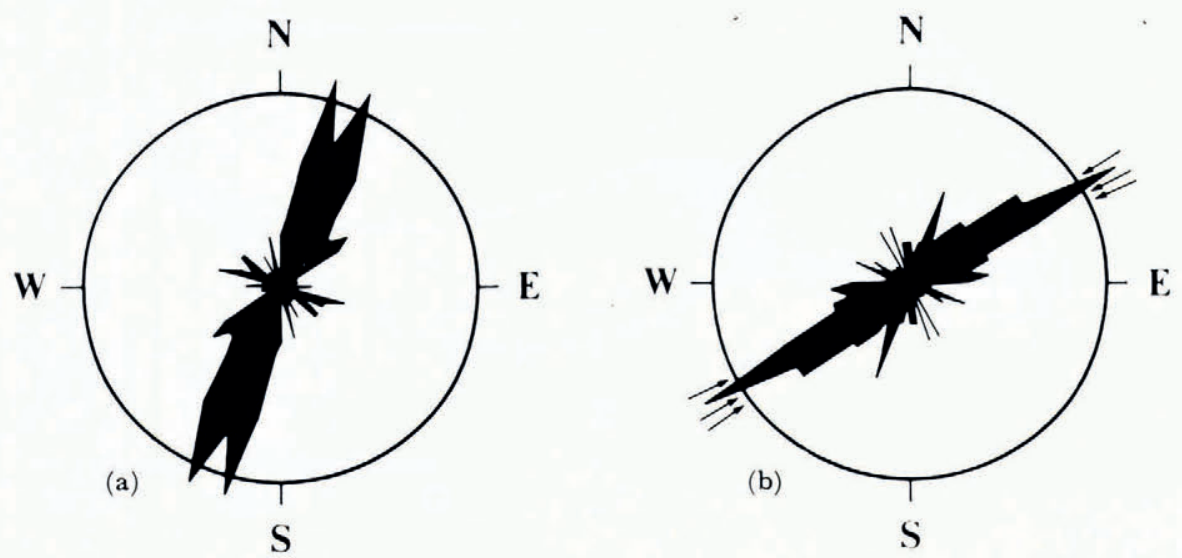

Fig. 13. Till-fabric measurements in the chalk quarry at Hemmoor: (a) I20 measurements of long axes in the Main Drenthe till in the south-western part of the quarry. (b) Ioo measurements of long axes in the Main Drenthe till in the southeastern part of the quarry. The circle indicates $10 \%$ in both cases. Arrows: direction of "undulations" at the base of the till in the south-eastern part of the exposure. 
This direction coincides with the till-fabric measurements of Grube and Höfle, and thercfore most likely with the direction of movement of the Drenthe ice (Fig. 13).

There are several possible explanations for these "undulations". Some of the small ones could have been formed by furrowing of the underlying surface by larger boulders in the same way as the formation of the "ribs". However, until now no proof of this has been found. The

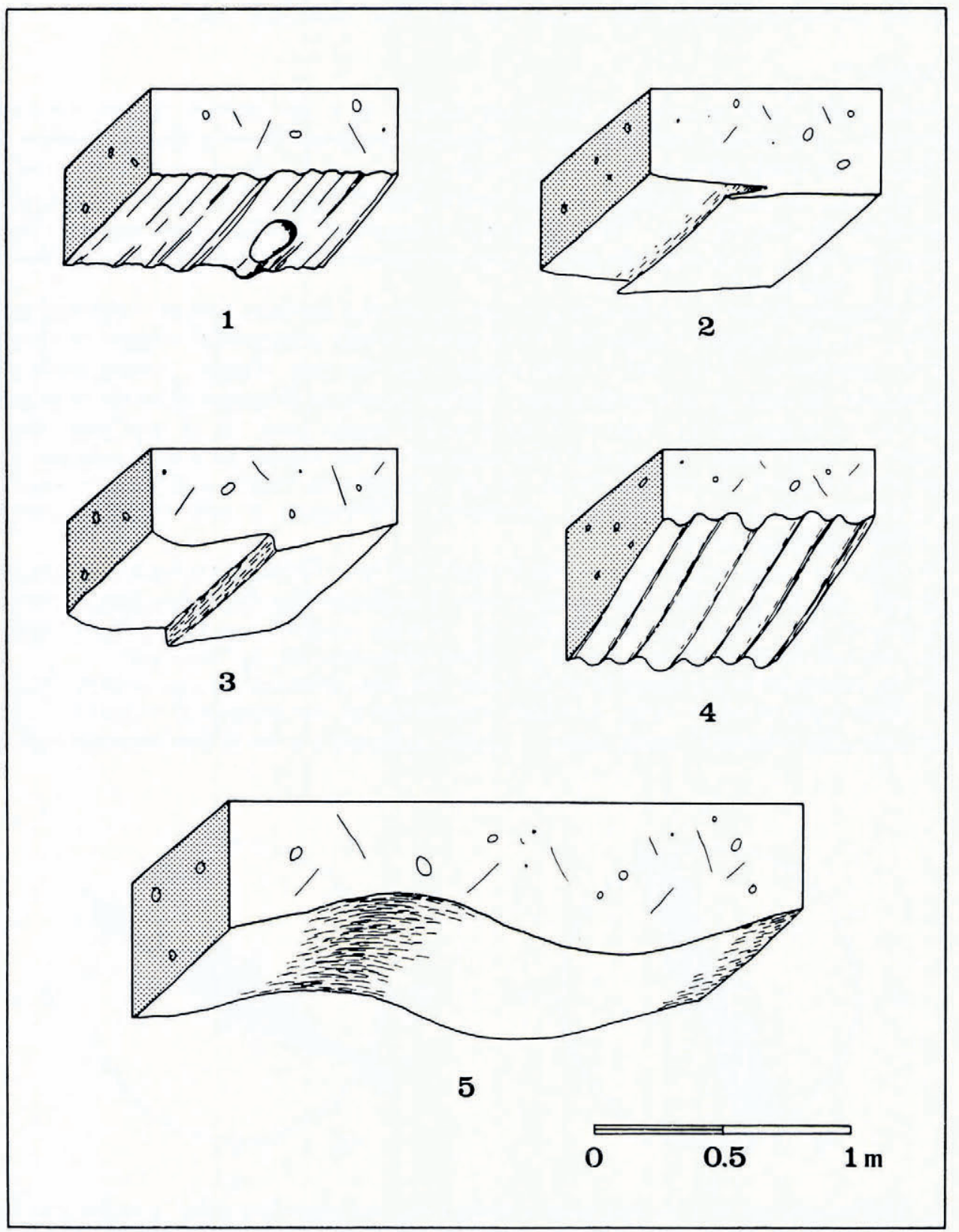

Fig. 14. Diagrammatic sketch showing the observed phenomena: t. "Ribs"; 2. "Wedge"; 3. "Edge"; 4. Slickenside; 5. "Undulation". 
vast majority were probably formed by restricting latitudinal shearing movements at the base of the ice when it, for example, flowed over or around an olstacle. This explanation is supported by the fairly frequent association of "undulations" with "wedges" (see lig. 12).

\section{(ioncitisions}

The direction of the ice movement is often reconstructed with the aid of till-fabric measurements. However. since the maximum of a till-fabric measurement does not in all cases lic parallel to the direction of the ice movement (see discussion in Boulton $\left({ }^{\circ} 1971\right], p .68$ ), Stephan (1971, p. 78), cf. Dreimanis (|c1976|, p. 31)) or because several maxima are possible as, for example, in the exposures near St. Michaelisdonn. Burg/1)ithmarschen, and Hemmoor (Figs 2, 9, and 13), the results of the measurements can be checked in certain places where the forms described in this paper can be observed. A visual comparison of the different forms is given in Figure 14. These forms are important for the glacial geologist insofar as they allow him to measure directly the local line of flow of the ice and, where a "rib" ends at a stone, directly to read off even the local flow direction. In these circumstances, he may dispense with the time-consuming method of till-fabric measurements.

Unfortunately, the lower surfaces of Pleistocene tills are often so encrusted by re-deposited iron and lime that fine forms which were perhaps there originally are no longer discernible. In these cases and where a deformation till (according to Dreimanis ( $\left[{ }^{c} 1976\right]$, p. 19)) appears between the actual basal till and the underlying sediments, no useful furrows or grooves ("ribs" at the till base) can be expected to be found. It seems that the type of underlying sediment also plays a part. Well-formed "ribs" have until now only been found on sands of fine or medium grain which were relatively well sorted. The only exception is the Heiligenhafen cliff described above.

"Edges" and "wedges" are much more common than "ribs". In all events, it is worthwhile looking out for these forms. Previously they have been overlooked in many cases because of the difficulty of examining the lower surface of a till.

\section{Acknowlengements}

Thanks are due to F. Grube, H.-C. Höfle, H. Ross, G. Schlüter, and G. Scifert, who kindly gave us the results of their stone counts and measurements. We are also grateful to G. and E. Gaumnitz, who translated our manuscript into English.

\section{MS. received 13. January 1978 and in revised form 21 . April 1978}

\section{REFERENC:ES}

Boulton, G. S. ["1971.] Till genesis and fabric in Svalbard, Spitsbergen. (In Goldthwait, R. P., ed. Till: a symposium. [Columbus], Ohio State University Press, p. 41-72.)

Boulton, G. S. 1976. The origin of glacially fluted surfaces-observations and theory. Journal of Gilaciolog), Vol. 17 , No. 76, p. $287-309$.

Dreimanis, A. [ ${ }^{1} 1976$.] Tills: their origin and properties. (In Legget, R. F., ed. Glacial till. An interdisciplinary study. [Ottawa], Royal Society of Canada in co-operation with the National Research Ciouncil of Cianada, p. i 1-49. (Royal Society of ('anada Special Publications, No. 12.))

Ehlers, J. 1975. Neue Untersuchungen zur Entstehung der Harburger Berge. Harburger Jahrbuch, 14 , p. 749 .

Morris, E. M., and Morland, L. W. 1976. A theoretical analysis of the formation of glacial flutes. Fournal of Glaciology, Vol. 17 , No. 76 , p. $3^{1} 1^{-2} 3$.

Olszewski, A. 1974. Jednostki litofacjalne glin subglacjalnych nad dolną Wisłą w świetle analizy ich makrostruktur i makrotekstur [Lithofacial units of subglacial boulder clays on the lower Vistula in the light of the analysis of their macrostructures and macrotextures]. Studia Societatis Scientiarum Torunensis, Vol. 8, Sect. C, Nr. 2.

Seifert, G. 1952. Gletscherschrammen auf Fehmarn (Schleswig-Holstein). Naturwissenschaften, Bd. 39, Ht. 23, p. $55^{\mathrm{I}}$.

Stephan, H.-J. 1971. Glacialgeologische Untersuchungen im Raum Heiligenhafen (Ostholstein). Meyniana: Veröffentlichungen aus dem Geologischen Institut der Universität Kiel, Bd. 21, p. 41-66. 